\title{
Spot urine protein/creatinine ratio-A quick and accurate method for diagnosis of pre-eclampsia
}

\author{
Amita Sharma ${ }^{1}$, Pandey Kiran ${ }^{2}$, Bhagoliwal Ajai ${ }^{3}$ \\ ${ }^{1}$ Department of Obstetrics and Gynecology, VCSGGMS \& RI, Srinagar, India \\ ${ }^{2}$ Department of Obstetrics and Gynecology, G.S.V.M. Medical College, Kanpur, India \\ ${ }^{3}$ Department of Community Medicine, G.S.V.M. Medical College, Kanpur, India \\ Email: dramita99@gmail.com
}

Received 3 August 2013; revised 2 September 2013; accepted 10 September 2013

Copyright (C) 2013 Amita Sharma et al. This is an open access article distributed under the Creative Commons Attribution License, which permits unrestricted use, distribution, and reproduction in any medium, provided the original work is properly cited.

\begin{abstract}
Objective(s): To assess the diagnostic accuracy of spot urine protein-creatinine $(\mathrm{P} / \mathrm{C})$ ratio and its compareson with 24-hour urine proteinuria for predicting eclampsia. Method(s): Spot urine P/C ratio was determined in a mid-stream urine sample, and the 24hour urine protein was measured. The correlation between the spot $\mathrm{P} / \mathrm{C}$ ratio and 24-hour urine protein amount was done. Logistic regression analysis and ROC curve analysis have been used to analyse data. Result(s): There was a strong correlation between the spot $\mathrm{P} / \mathrm{C}$ ratio and 24-hour urine protein excretion (pearson's correlation coefficient $r=0.71 ; P<0.0001$ ). The optimal spot $\mathrm{P} / \mathrm{C}$ ratio cutoff point was 0.25 , for $300 \mathrm{mg} / 24 \mathrm{~h}$ of protein excretion, with sensitivity and specificity of $69 \%$ and $75 \%$ respectively. Conclusion(s): Spot urine $\mathrm{P} / \mathrm{C}$ ratio is a quick and reliable tool which can be used as an alternative method for evaluation of proteinuria for diagnosis of pre-eclampsia.
\end{abstract}

Keywords: Urine Protein-Cretinine Ratio; 24 Hour Urine Proteinuria; Pre-Eclampsia; Cutoff Point

\section{INTRODUCTION}

Pre-eclampsia is a multisystem disorder complicating 5\% - $10 \%$ of pregnancy [1]. Pre-eclampsia is a major cause of maternal and fetal morbidity and mortality in India. This is a pregnancy specific syndrome of reduced organ perfusion secondary to vasospasm and endothelial activation [2]. The minimum criteria for the diagnosis of pre-eclampsia are hypertension plus proteinuria. Proteinuria is an important sign of pre-eclampsia. Significant proteinuria is described as $300 \mathrm{mg}$ or more of urine protein per 24 hours period. The gold standard for diagnosis of significant proteinuria is 24 hours urine collections
[3].

However the collection of urine for 24 hours is timeconsuming and needs strong co-operation; requires hospitalization, inconvenient, costly and inaccurate due to incomplete collection and poor compliance. This can delay diagnosis and management of pre-eclampsia.

A more rapid test capable of accurately predicting end results of 24 hours urine is required. An alternative method for quantitative evaluation of proteinuria is the measurement of protein-creatinine ratio in spot urine sample, which avoids the influence of variation in urinary solute concentration and provides a more convenient and rapid method to assess protein excretion [4]. A rapid and accurate test may provide efficient in-patient and outpatient monitoring of proteinuria and may shorten the duration of hospitalization. This study was conducted to assess the diagnostic accuracy and determine an optimum cut-off point of spot urine protein-creatinine ratio for the prediction of significant proteinuria in patients with pre-eclampsia.

\section{MATERIAL AND METHODS}

The present study was planned as a prospective study which include 140 pregnant women of $\geq 20$ weeks of gestation period and $\geq 140 / 90 \mathrm{mmhg}$ Blood pressure, admitted in Upper India Sugar Exchange, Dept. of Gynaecology, G.S.V.M. Medical College, Kanpur over a period of 18 months during January, 2009 to June, 2010.

A detailed history with thorough clinical examination and routine investigations, liver function test, renal function test was done to select women. Women with chronic hypertension, intrinsic renal disease, liver disease, coexisting urinary tract infection, Gestational diabetes mellitus, Inadequate specimen, Heavy exercise-more than 1hour, Bacteremia, Strict bed rest longer than 24 hours were excluded from the study. 
All women included in the study irrespective of the severity of disease were asked to provide spot mid stream urine sample and collect all the urine subsequently for 24 hours period. The urine protein-creatinine ratio was determined on spot urine specimen. Total urine protein quantification was done by well established, Biuret calorimetric assay and urine-creatinine estimation was done by modified Jaffe's method. The urine $\mathrm{P} / \mathrm{C}$ ratio was obtained by dividing the total urine protein concentration by the urine creatinine concentration.

The relationship between protein-creatinine ratio and 24-hour protein excretion was assessed by Pearson correlation coefficient. Sensitivity, specificity, positive predictive value and negative predictive value of random urine protein creatinine ratio at various cut offs for prediction of significant proteinuria were estimated with a $95 \%$ confidence interval $(95 \% \mathrm{CI})$, using the results of 24-hour urine collection as gold standard.

The received operating characteristic (ROC) curve analysis was used to determine the best discriminator values of the spot urine protein-creatinine ratios for preeclampsia (proteinuria $\geq 300 \mathrm{mg} / 24 \mathrm{hr}$ ). A P value of 0.05 was considered to be significant. The SPSS software was used for the statistical analyses.

\section{RESULTS}

In this study a total of 126 pregnant women with preeclampsia were selected according to the inclusion and exclusion criteria.14 were excluded from the study, 7 were delivered before completion of 24 hour urine collection, 3 were diagnosed with chronic hypertension and 4 were having urinary tract infection.

Table 1 shows age group 21 to 30 years contributed the highest percentage $(87.92 \%)$. Majority of subjects were nulliparous (46.03\%), followed by primipara (19.04\%). Majority of subjects having high blood pressure were belong to group 28 to 32 week gestational age (42.06\%), followed by group 33 to 36 weeks gestational age (31.74\%). Mean systolic blood pressure was $160.79 \pm 15.16$ and diastolic blood pressure was $104.37 \pm 13.653$ at admission.

The mean urinary protein excretion in 24 hours was $1067.8 \pm 78 \mathrm{mg} / \mathrm{dl}$ (range, $200 \mathrm{mg} / \mathrm{dl}$ to $3000 \mathrm{mg} / \mathrm{dl}$ ). The mean $\mathrm{P} / \mathrm{c}$ ratio was $0.338 \pm 0.15$ (range 0.143 to 0.72 ). The correlation coefficient for the $\mathrm{P} / \mathrm{C}$ ratio against the 24 hour urine protein excretion was $0.71\left(R^{2}=0.71\right)$.

The predictor model of regression equation was $\mathrm{Y}=$ $-269.19+3715.15 \mathrm{X},(\mathrm{P}<0.0001)$ where $\mathrm{X}=$ spot protein creatinine ratio and $\mathrm{Y}=24$ hour urine protein.

Figure 1 shows the relationship between 24 hours protein excretion and spot protein-creatinine $(\mathrm{P} / \mathrm{C})$ ratio. The curve indicates very good linear relationship between the two variables which is also indicated by strong correlation coefficient $(r=0.71, \mathrm{P}=0.0001)$.
Table 2 shows calculation of area under the curve that was 0.793 with $95 \%$ confidence interval. True area for null hypothesis was 0.5 . Thus our hypothesis was true, Area under the curve 0.79 indicates that the spot urine

Table 1. Distribution of cases according to clinical parameters.

\begin{tabular}{|c|c|c|c|c|}
\hline $\begin{array}{c}\text { Range } \\
\text { Age (years) }\end{array}$ & $\begin{array}{c}\text { No. of cases } \\
(n=126)\end{array}$ & Percentage & Mean & SD \\
\hline$<20$ & 9 & 7.14 & 25.151 & 3.769 \\
\hline $21-30$ & 107 & 87.92 & & \\
\hline $31-40$ & 10 & 7.9 & & \\
\hline Parity & & & 1.262 & 1.465 \\
\hline $\mathrm{P} 0$ & 58 & 46.03 & & \\
\hline $\mathrm{P} 1$ & 24 & 19.04 & & \\
\hline $\mathrm{P} 2$ & 16 & 12.7 & & \\
\hline $\begin{array}{l}\text { Gestational age } \\
\text { (in weeks) }\end{array}$ & No. of cases & Percentage & 33.96 & $3 . .260$ \\
\hline $28-32$ & 53 & 42.06 & & \\
\hline $33-36$ & 40 & 31.74 & & \\
\hline $37-40$ & 31 & 24.60 & & \\
\hline$>40$ & 2 & 1.58 & & \\
\hline $\begin{array}{c}\text { Systolic Blood } \\
\text { pressure }(\mathrm{mm} \cdot \mathbf{H g})\end{array}$ & No. of cases & Percentage & 160.79 & 15.158 \\
\hline$<160$ & 50 & 39.68 & & \\
\hline$\geq 160$ & 76 & 60.32 & & \\
\hline $\begin{array}{c}\text { Diastolic blood } \\
\text { pressure }(\mathrm{mm} \cdot \mathrm{Hg})\end{array}$ & No. of cases & Percentage & 104.37 & 13.653 \\
\hline$<110$ & 74 & 58.73 & & \\
\hline$>110$ & 52 & 41.27 & & \\
\hline
\end{tabular}

Table 2. Area under the curve. Test result variable(s): VAR 0001 .

\begin{tabular}{ccccc}
\hline \multirow{2}{*}{ Area } & Std. Error $^{\mathrm{a}}$ & Asymptotic Sig $^{\mathrm{b}}$ & \multicolumn{2}{c}{$\begin{array}{c}\text { Asymptotic 95\% } \\
\text { Confidence Interval }\end{array}$} \\
\cline { 4 - 5 } & & & Lower Bound & Upper Bound \\
\hline 0.793 & 0.068 & 0.001 & 0.659 & 0.927 \\
\hline
\end{tabular}

${ }^{\mathrm{b}}$ Null hypothesis: true area $=0.5$.

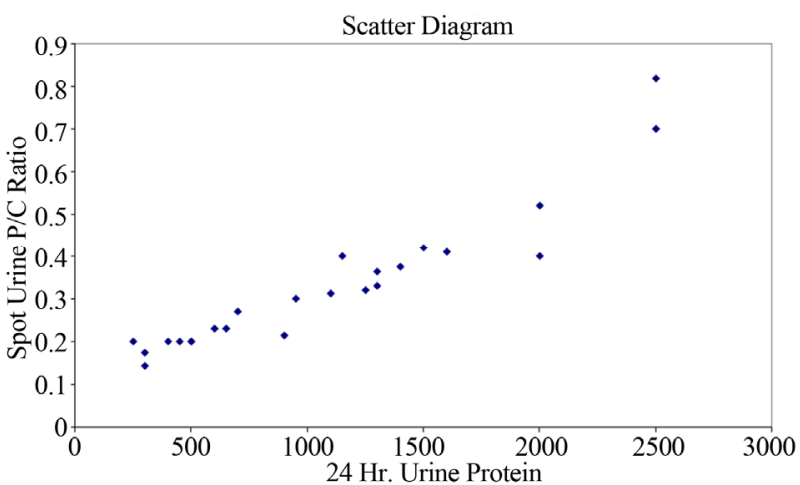

Figure 1. Scatter diagram. 
protein creatinine ratio provides excellent discrimination.

Figure 2 shows ROC curve, area under the curve was 0.793 (with $95 \% \mathrm{CI}, \mathrm{P}<0.001$ ).

In Figure 3 graph is showing sensitivity and specificity at different level of spot urine protein creatinine ratio. This graph shows that with increasing sensitivity the specificity of spot protein creatinine ratio were decreased at various cut off points. At 0.14 cut off value, sensitivity was highest $99.1 \%$ and specificity $50 \%$. At cut off value 0.37 , the sensitivity $31 \%$ and specificity $100 \%$. At cut off $\mathrm{p} / \mathrm{c}$ ratio 0.25 was identified as the best threshold to detect $24 \mathrm{hrs}$ urine protein excretion of $300 \mathrm{mg} / 24 \mathrm{hr}$ with sensitivity and specificity $69 \%$ and $75 \%$. The positive predictive value was $92.3 \%$ and negative predictive value was $90.4 \%$.

Table 2 shows area under the curve with 95\% confidence interval.

Figure 2 shows ROC curve, the area under the curve has been calculated, which came out to be 0.79 .

In Figure 3, graph showing sensitivity and specificity at different levels of spot urine $\mathrm{P} / \mathrm{C}$ ratio.

\section{DISCUSSION}

Pre-eclampsia is the 3rd leading cause of maternal mor-

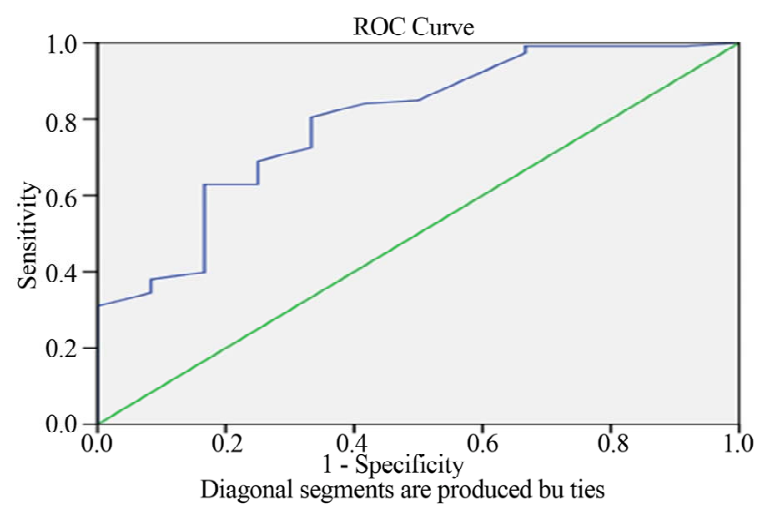

Figure 2. ROC curve.

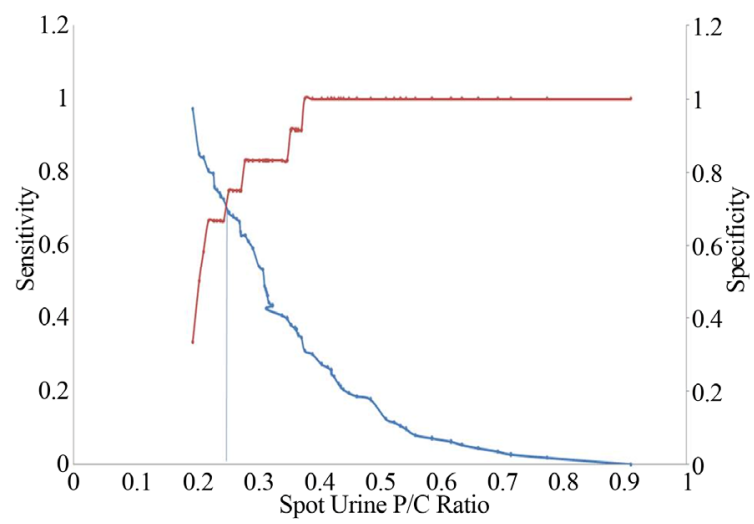

Figure 3. Sensitivity and specificity at different levels of spot urine $\mathrm{P} / \mathrm{C}$ ratio. tality and morbidity [1]. The present study included 126 women with pregnancy induced hypertension. The highest incidence of PIH was found in the age group $21-30$ yrs $(87.92 \%)$ in our study with the mean age of total patients being $25.151 \pm 3.77$ yrs. Majority of patients of $\mathrm{PIH}$ in our study were nulliparous $(46.03 \%)$. Majority of subjects having high blood pressure were belonged in group 28 - 32 weeks gestational age $(42.06 \%)$. In our study majority of cases had systolic blood pressure $\geq 160$ $\mathrm{mm} \cdot \mathrm{Hg}(60.32 \%)$ and diastolic blood pressure $<110$ $\mathrm{mm} \cdot \mathrm{Hg}(58.73 \%)$. This is supported by the findings of $\mathrm{J}$. O. Eigbefoh et al. [5] who has also reported the maximum incidence in age group 20 - 29 years $(75.6 \%)$ followed by age group 32 - 39 years and majority of subject were nullipara $(54.7 \%)$ followed by primipara $(15.15 \%)$.

In our study sensitivity, specificity, positive predictive value, and negative predictive value calculated at various cut off points of $\mathrm{P} / \mathrm{C}$ ratio. Maximum sensitivity $99.1 \%$ was found with protein creatinine ratio cut off point 0.14 and maximum specificity $100 \%$ was found with protein creatinine ratio cut off point 0.37 . A very good linear relationship exists between $24 \mathrm{hr}$ protein excretion and spot protein creatinine ratio with strong correlation coefficient $(\mathrm{r}=0.71, \mathrm{P}=0.0001)$.

By the Receiver Operating Characteristic (ROC) curve analysis, the area under the curve has been calculated, which came out to be 0.79 which indicates that the spot urine $\mathrm{P} / \mathrm{C}$ ratio provides excellent discrimination (Table 2 ). The $\mathrm{P} / \mathrm{C}$ ratio of 0.25 was identified as the best cutoff point to detect urine protein excretion of $>300 \mathrm{mg} / 24$ $\mathrm{hr}$. The positive predictive value was $92.3 \%$ and negative predictive value was $90.4 \%$.

Attempts for establishing spot $\mathrm{P} / \mathrm{C}$ ratio as a marker for pre-eclampsia have been done past also. Durnwald and Mercer [6] determined lower correlation coefficients of 0.56 and 0.41 and cautioned against substituting spot $\mathrm{P} / \mathrm{C}$ ratio for the 24 hour urine protein collection. Al and colleagues [4] found significant association between 24 -hour protein and random protein-creatinine ratio $(\mathrm{r}=$ $0.56, \mathrm{P}<0.01)$. With a cut off protein creatinine ratio greater than 0.19 as a predictor of significant proteinuria, sensitivity and specificity were $85 \%$ and $73 \%$. Positive and negative predictive values were $46 \%$ and $95 \%$ respectively. Wheeler and colleagues [7] found in their study, that the $\mathrm{P} / \mathrm{C}$ ratio of $0.46,0.82$ and 3.0 represented $1000 \mathrm{mg} / 24 \mathrm{~h} 2000 \mathrm{mg} / 24 \mathrm{hr}$ and $3000 \mathrm{mg} / 24 \mathrm{hr}$, respectively. All of these were characterized by excellent accuracy. The urine $\mathrm{P} / \mathrm{C}$ ratio of 0.21 corresponded with a protein excretion rate of $300 \mathrm{mg} / 24 \mathrm{hr}$. The area under curve was $0.8 \%$ indicating good accuracy which supports our findings. Nahid Shahbazian et al. [8] found the strong correlation between the spot $\mathrm{P} / \mathrm{C}$ ratio and $24 \mathrm{hr}$ urine protein excretion $(\mathrm{r}=0.84, \mathrm{P}<0.001)$. The optimal spot $\mathrm{P} / \mathrm{C}$ ratio cut off point was 0.2 for $300 \mathrm{mg} / 24 \mathrm{hr}$ of 
protein excretion, with a sensitivity, specificity, positive predictive value and negative predictive value of $91.2 \%$, $87.8 \%, 94.4 \%$ and $96.8 \%$ respectively.

Our study suggests that the spot urine protein creatinine ratio provides excellent discrimination between insignificant and significant proteinuria in preeclampsia. This test can be used for prompt clinical decision in spite of waiting for $24 \mathrm{hr}$ urine collection. Drawback of our study is large number of false negative cases $(30 \%)$. Further studies should be done large sample size and utility of this test in ambulatory management of preeclamptic patients.

\section{CONCLUSION}

There is a strong correlation between spot urine $\mathrm{P} / \mathrm{C}$ ratio and the 24 hour urine protein excretion. Spot urine protein-creatinine ratio can be used to predict the amount of 24 hours urine protein excretion with high accuracy. But the $24 \mathrm{hr}$ urine collection remains the gold standard for evaluation for pre-eclampsia. So, spot urine protein-creatinine ratio can be used for detection of significant proteinurea in pregnant women with suspected pree-clampsia with high accuracy, which is more rapid than 24 hour urine protein excretion. Thus this quick method with high accuracy is very useful to prevent feto-maternal morbidity and mortality in India.

\section{REFERENCES}

[1] Majhi, A.K., Mondal, A. and Mukherjee, G.G. (2001) Safe motherhood-A long way to achieve. Journal of In- dian Medical Association, 99, 132-137.

[2] Granger, J.P., Alexander, B.T., Llinas, M.T., Bennett, W.A., Khalil, R.A. (2001) Pathophysiology of hypertension during pre-eclampsia linking placental ischemia with endothelial dysfunction. Hypertension, 38, 718-722. http://dx.doi.org/10.1161/01.HYP.38.3.718

[3] (2000) Report of the national high blood pressure education program working group on high blood pressure in pregnancy. American Journal of Obstetrics and Gynecology, 183, S1-S22.

http://dx.doi.org/10.1067/mob.2000.107928

[4] Al, R.A., Baykal, C., Karacay, O., Geyik, P.O., Altun, S. and Doten, I. (2004) Random urine protein creatinine ratio to predict protenuria in new onset mild hypertension in late preganncy. Obstetrics \& Gynecology, 104, 367- 371. http://dx.doi.org/10.1097/01.AOG.0000134788.01016.2a

[5] Eigbejoh, J.O., Abebe, J., Odike, M.A. and Isabu, P. (2007) Protein/creatinine ratio in random urine specimen for quantitation of proteinuria in pre-eclampsia. Internet Journal of Gynecology \& Obstetrics, 7, 6.

[6] Durnwald, C. and Mercer, B. (2003) A prospective comparison of total protein/creatinine ratio versus 24-hour urine protein in women with suspected pre-eclampsia. American Journal of Obstetrics \& Gynecology, 189, 848852. http://dx.doi.org/10.1067/S0002-9378(03)00849-4

[7] Wheeler 2nd, T.L., Blackhurst, D.W., Dellinger, E.H. and Ramsey, P.S. (2007) Usage of spot urine protein to creatinine ratios in the evaluation of pre-eclampsia. American Journal of Obstetrics \& Gynecology, 196, 465e1-4.

[8] Shahbazian, N. and Farjanet Hosseini-Asl, F. (2008) A comparison of spot urine protein-creatinine ratio with 24 hours urine protein excretion in women with pre-eclampsia. Iranian Journal of Kidney Diseases, 2,127-131.

\author{
ABBREVIATIONS \\ $\mathrm{P} / \mathrm{C}$ ratio-protein/creatinine ratio \\ ROC curve-received operating characteristics curve \\ CI-coefficient interval
}

